INDONESIA ACCOUNTING JOURNAL

VOLUME 1, NUMBER 2, YEAR 2019

${ }^{1}$ Corresponding author

Jurusan Akuntansi

Fakultas Ekonomi dan Bisnis

Universitas Sam Ratulangi

Jl. Kampus UNSRAT

Manado, Indonesia, 95115

E-mail : lusiamissah@yahoo.com

${ }^{2,3}$ Jurusan Akuntansi

Fakultas Ekonomi dan Bisnis

Universitas Sam Ratulangi

Jl. Kampus UNSRAT

Manado, Indonesia, 95115

Article info:

Received 28 October 2019

Accepted 28 October 2019

Available online 28 October 2019

Keywords: Characteristics of management accounting information; managerial performance

JEL Classification: M41

DOI : http://doi.org/10.3240o/iaj. 26176

\section{Pengaruh karakteristik informasi akuntansi manajemen terhadap kinerja manajerial pada PT. Bank Sulutgo $\odot$}

\author{
Lusia N Missah ${ }^{1}$ \\ Ventje Ilat ${ }^{2}$ \\ Victorina Z Tirayoh ${ }^{3}$
}

\begin{abstract}
Increasing business competition requires companies to make the most of existing capabilities to excel in competition. This can be achieved by increasing managerial performance. In its operations, PT Bank SulutGo really needs and relies on every internal and external information. This study aims to determine the effect of the characteristics of management accounting information of managerial performance at PT Bank SulutGo. This research uses quantitative research methods. For data analisys methods using multiple linear regression analisys. The results showed that: (1) broadscope variable influences managerial performance; (2) the timeliness variable influences managerial performance; (3) the aggregation variable influences managerial performance; and (4) variable integration has no effect on managerial performance.
\end{abstract}

\section{Pendahuluan}

Penggunaan karakteristik informasi akuntansi manajemen merupakan salah satu cara unuk menata memperbaiki dan meningkatkan kinerja perusahaan agar mampu memberikan layanan yang terbaik bagi pelanggannya. Kinerja PT Bank SulutGo mengalami peningkatan, itu dibuktikan dengan berhasil mencapai target pertumbuhan aset hingga kuartal 1/2019. Sampai akhir Maret, total aset Bank SulutGo tercatat Rp 16,76 triliun, atau tumbuh 7,38\% secara tahunan. Kinerja manajerial pada PT Bank SulutGo akan semakin baik dan meningkat ketika informasi yang diperoleh memenuhi karakteristik informasi sistem akuntansi manajemen.

\section{Tinjauan pustaka}

Pengertian akuntansi. Akuntansi adalah seni pencatatan, penggolongan, pengikhtisaran, dan pelaporan atas suatu transaksi dengan cara sedemikian rupa, sistematis dari segi isi dan berdasarkan standar yang diakui umum, (Bahri, 2016:2). Akuntansi sebagai suatu aktiva jasa yang terdiri dari mencatat, mengklasifikasikan, dan melaporkan kejadian atau transaksi ekonomi yang akhirnya menghasilkan suatu informasi keuangan yang akan dibutuhkan oleh pihak-pihak tertentu untuk pengambilan keputusan (Purba et al., 2018).

Akuntansi manajemen. Menurut Rudianto (2014:4), akuntansi manajemen merupakan sistem alat, yakni jenis informasi yang dihasilkan ditujukan kepada pihakpihak internal organisasi, seperti manajer keuangan, manajer produksi, manajer pemasaran dan sebagainya guna pengambilan keputusan internal organisasi. Akuntansi manajemen adalah penerapan konsep dan metode yang tepat dalam mengelola data ekonomi masa lalu dan membuat proyeksi masa depan suatu usaha untuk membantu manajemen dalam penyusunan rencana (tujuan) perusahaan 
dan pengambilan keputusan untuk mencapai tujuan tersebut (Antameng et al., 2017). Sistem akuntansi manajemen adalah sistem yang mengumpulkan data operasional dan finansial, memprosesnya, menyimpannya, dan melaporkannya kepada pengguna yaitu para pekerja, manajer, dan eksekutif (Butarbutar et al., 2017).

Karakteristik informasi akuntansi manajemen. Ada 4 karakteristik informasi akuntansi manajemen (1) Karakteristik Broadscope yaitu mengacu pada dimensi fokus, kuantifikasi dan horizon waktu. (2) Karakteristik Timeliness menyatakan ketepatan waktu dalam memperoleh informasi mengenai suatu kejadian. (3) Karakteristik Aggregation merupakan ringkasan informasi menurut fungsi, periode waktu, dan model keputusan. (4) Karakteristik Integration adalah aspek pengendalian suatu organisasi yang penting adalah koordinasi berbagaim segmen dalam sub-sub organisasi.

Konsep informasi. Informasi adalah data yang diolah kedalam suatu bentuk yang berguna bagi penerimanya yang nyata atau berupa nilai yang dapat dipahami di dalam keputusan sekarang maupun masa depan (Mardi 2014:5).

Konsep kinerja manajerial. Kinerja adalah hasil dari prestasi kerja yang merupakan hasil dari implementasi rencana kerja yang dibuat oleh suatu institusi yang dilakasanakan oleh pimpinan dan karyawan yang bekerja di instansi baik dipemerintahan maupun perusahaan bisnis untuk mencapai tujuan organisasi (Abdullah, 2014:4). Kinerja adalah hasil dari suatu proses yang mengacu dan diukur selama periode waktu tertentu berdasarkan ketentuan atau kesepakatan yang telah ditetapkan sebelumnya (Edison, 2016). Kinerja atau prestasi kerja adalah hasil atau tingkat keberhasilan seseorang secara keseluruhan dalam periode tertentu dalam melaksanakan tugas dibandingkan dengan berbagai kemungkinan, seperti standar hasil kerja, target atau sasaran atau kriteria yang telah ditentukan terlebih dahulu dan disepakati bersama (Benawan et al., 2018). Kinerja manajerial adalah kemampuan manajer dalam melaksanakan kegiatan manajerial, antara lain: perencanaan, investigasi, koordinasi, evaluasi, supervisi, pengaturan staf (Nuraidah, 2017). Menurut Menurut Rivai (2014) faktor-Faktor yang mempengaruhi kinerja manajerial antara lain Pengetahuan dan kemampuan dari segi teknis, konseptual, dan interpersonal merupakan modal utama perusahaan untuk perkembangan kedepannya. Menurut Badriah (2015), tujuan penilaian kinerja yaitu untuk pengembangan tujuan organisasi dan untuk mengevaluasi terhadap tujuan organisasi.

Penelitian terdahulu. Prasasti (2017) menunjukan terdapat pengaruh karakteristik sistem informasi akuntansi manajemen terhadap kinerja manajerial. Wicakcono (2014) menemukan bahwa variabel karakteristik informasi sistem akuntansi manajemen berpengaruh positif terhadap performa manajemen.

Hipotesis. Hipotesis penelitian dikembangakan dari teori-teori dan penelitian terdahulu. Berikut empat hipotesis yang terdapat dalam penelitian ini.

$\mathrm{H}_{1}$ : Broadscope berpengaruh secara signifikan terhadap kinerja manajerial.

$\mathrm{H}_{2}$ : Timeliness berpengaruh secara signifikan terhadap kinerja manajerial.

$\mathrm{H}_{3}$ : Aggregation berpengaruh secara signifikan terhadap kinerja manajerial.

$\mathrm{H}_{4}$ : Integration berpengaruh secara signifikan terhadap kinerja manajerial.

\section{Metode penelitian}

Jenis dan sumber data. Jenis data yang digunakan dalam penelitian ini adalah data kuantitatif yaitu data subyek yaitu data berupa respon tertulis dari reponden berkaitan dengan butir-butir pernyataan dari masing-masing indikator dari setiap variabel yang diaplikasikan melalui kuesioner penelitian sebagai instrumen penelitian.

Sampel dan teknik pengambilan sampel. Dalam penelitian ini, metode sampling yang digunakan adalah teknik sampling jenuh yaitu teknik penentuan sampel bila semua anggota populasi digunakan sebagai sampel. Jadi dalam penelitian ini semua anggota populasi menjadi sampel. 
Metode analisis. Dalam penelitian ini data yang diperoleh akan dianalisis menggunakan Analisis Regresi Linier Berganda. Analisis linier berganda adalah analisis yang megukur dua atau lebih variabel independen, terhadap variabel dependen, sedangkan hubungannya tetap linear (Taniredja dan Mustafidah, 2014:92).

\section{Hasil analisis dan pembahasan}

\subsection{Hasil analisis}

Uji validitas. Uji validitas digunakan untuk mengukur sah atau valid tidaknya suatu kuisioner. Hasil uji validitas untuk semua variabel menunjukan menunjukan bahwa semua butir instrumen dinyatakan valid karena nilai $\mathrm{r}$ hitung $>$ nilai $\mathrm{r}$ tabel $(0,324)$ sehingga dapat digunakan sebagai alat pengumpulan data.

\begin{tabular}{lclccc}
\multicolumn{1}{c}{ Tabel 1. Hasil uji validitas } & & & \\
\hline \multicolumn{1}{c}{ Variabel } & No & $\begin{array}{c}\text { Butir } \\
\text { Pertanyaan }\end{array}$ & $\begin{array}{c}\text { r } \\
\text { hitung }\end{array}$ & $\begin{array}{c}\text { r } \\
\text { tabel }\end{array}$ & Ket \\
\hline \multirow{2}{*}{ Broadscope } & 1 & BS1 & 0.845 & 0.324 & Valid \\
& 2 & BS2 & 0.863 & 0.324 & Valid \\
\hline \multirow{2}{*}{ Timelines } & 1 & TL1 & 0.808 & 0.324 & Valid \\
& 2 & TL2 & 0.858 & 0.324 & Valid \\
\hline \multirow{2}{*}{ Aggregation } & 1 & AGR1 & 0.740 & 0.324 & Valid \\
& 2 & AGR2 & 0.832 & 0.324 & Valid \\
\hline \multirow{2}{*}{ Integration } & 1 & IGR1 & 0.899 & 0.324 & Valid \\
& 2 & IGR2 & 0.439 & 0.324 & Valid \\
\hline \multirow{5}{*}{ Kinerja } & 1 & KM1 & 0.499 & 0.324 & Valid \\
Manajerial & 2 & KM2 & 0.599 & 0.324 & Valid \\
& 3 & KM3 & 0.530 & 0.324 & Valid \\
& 4 & KM4 & 0.449 & 0.324 & Valid \\
& 5 & KM5 & 0.669 & 0.324 & Valid \\
& 6 & KM6 & 0.556 & 0.324 & Valid \\
& 7 & KM7 & 0.353 & 0.324 & Valid \\
& 8 & KM8 & 0.450 & 0.324 & Valid \\
\hline
\end{tabular}

Sumber: output SPSS 24, 2019

Uji Reliabilitas. Reliabilitas adalah alat untuk mengukur suatu kuisioner yang merupakan indikator dari variabel atau konstruk, suatu kuisioner dikatakan reliabel atau handal jika jawaban seseorang terhadap pernyataan adalah konsisten atau stabil dari waktu ke waktu.

\begin{tabular}{llcc}
\multicolumn{5}{l}{ Tabel 2. Hasil uji reliabilitas } \\
\hline No & Variabel & Cronbach's Alpha & Keterangan \\
\hline 1 & Broad scope & 0,868 & Reliabel \\
2 & Timeline & 0,855 & Reliabel \\
3 & Aggregation & 0,822 & Reliabel \\
4 & Integration & 0,750 & Reliabel \\
5 & Kinerja Manajer & 0,704 & Reliabel \\
\hline \multicolumn{5}{l}{ Sumber: output SPSS 24, 2019 }
\end{tabular}

Berdasarkan Tabel 2 terlihat bahwa pengujian reliabilitas diperoleh nilai semua variabel lebih besar dari 0,60 yang menurut kriteria bisa dikatakan reliabel.

\section{Uji Asumsi Klasik}

Uji Normalitas. Gambar 1 menunjukan bahwa kurva normal P-P Plot of Regression menunjukan bahwa garis diagonal dalam grafik tersebut menggambarkan keadaan ideal mengikuti garis distribusi normal.

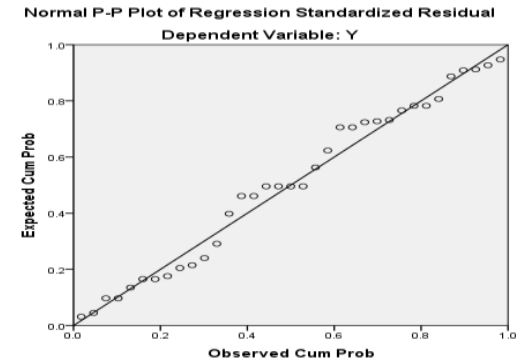

\section{Gambar 1. Grafik normalitas \\ Sumber: output SPSS 24, 2019}

Uji Multikolinearitas. Tabel 3 menunjukan bahwa semua nilai TOL $>0,10$ dan VIF $<$ 10, sehingga dapat disimpulkan tidak ada multikolonieritas antar independen dalam model ini.

Tabel 3. Hasil uji multikolinearitas

\begin{tabular}{|c|c|c|c|}
\hline Variabel & TOL & VIF & Keterangan \\
\hline $\begin{array}{l}\text { Broad } \\
\text { scope }\end{array}$ & 0.928 & 1.077 & $\begin{array}{c}\text { Tidak terjadi } \\
\text { multikolonieritas }\end{array}$ \\
\hline Timeline & 0.950 & 1.053 & $\begin{array}{c}\text { Tidak terjadi } \\
\text { multikolonieritas }\end{array}$ \\
\hline Aggregation & 0.929 & 1.076 & $\begin{array}{c}\text { Tidak terjadi } \\
\text { multikolonieritas }\end{array}$ \\
\hline Integration & 0.974 & 1.027 & $\begin{array}{c}\text { Tidak terjadi } \\
\text { multikolonieritas }\end{array}$ \\
\hline
\end{tabular}

Sumber: output SPSS 24, 2019

Uji Heteroskedastisitas. Gambar 2 menunjukkan bahwa distribusi data nampak tidak teratur dan tidak membentuk pola tertentu. Hal tersebut dapat dilihat pada plot yang menyebar dan terpencar diatas dan dibawah angka 0 pada sumbu $Y$, sehingga dapat disimpulkan bahwa pada model regresi ini tidak terjadi masalah heterokedastisitas. 


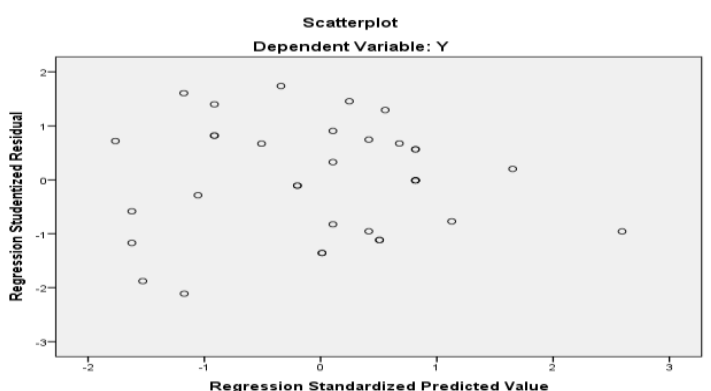

Gambar 2. Grafik heteroskedastisitas

Sumber: output SPSS 24, 2019

Hasil analisis linear berganda. Tabel 4 menunjukkan persamaan regresi linear berganda sebagai berikut:

$\mathrm{Y}=34,477+(0.475) \mathrm{X} 1+0,620 \mathrm{X} 2+(0,339) \mathrm{X} 3+(-$ $0,441) \mathrm{X} 4+3,204$

Interpretasi:

a. Nilai konstanta sebesar 34,477 , hal ini menunjukan apabila variabel broadscope, timeliness, aggregation, dan integration jika dianggap konstan (0), maka kinerja manajerial adalah 34,477 .

b. Koefisien regresi variabel broadscope (b1) sebesar 0,475. Hal ini berarti setiap kenaikan broadscope sebesar 1 satuan akan menaikan kinerja manajerial sebesar 0,475 satuan.

c. Koefisien regresi variabel timeliness (b1) sebesar 0,620. Hal ini berarti setiap kenaikan timeliness sebesar 1 satuan akan menaikan kinerja manjerial sebesar 0,620 satuan.

d. Koefisien regresi variabel aggregation (b1) sebesar 0.339. Hal ini berarti setiap kenaikan aggregation sebesar 1 satuan akan menaikan kinerja manjerial sebesar 0.339 satuan.

e. Koefisien regresi variabel integration (b1) sebesar -0,441. Hal ini berarti setiap kenaikan integration sebesar 1 satuan akan menaikan kinerja manjerial sebesar 0,414 satuan.

Tabel 4. Hasil uji regresi

\begin{tabular}{|c|c|c|c|c|c|c|}
\hline & & Unstan & ardized & Standardized & & \\
\hline & & Coeff & cients & Coefficients & & \\
\hline & Model & B & $\begin{array}{c}\text { Std. } \\
\text { Etror }\end{array}$ & Beta & $t$ & Sig. \\
\hline 1 & (Constant) & 34.477 & 3.204 & & 10.760 & 0.000 \\
\hline & Broadscope & 0.475 & 0.188 & 0.264 & 2.529 & 0.014 \\
\hline & Timeliness & 0.620 & 0.214 & 0.298 & 2.889 & 0.005 \\
\hline & Aggregation & 0.339 & 0.193 & 0.183 & 1.752 & 0.044 \\
\hline & Integration & -0.441 & 0.254 & -0.179 & -1.738 & 0.086 \\
\hline
\end{tabular}

Uji Koefisien Determinasi $\left(\mathbf{R}^{2}\right)$. Dari di atas, menunjukan bahwa nilai $R$ square $\left(R^{2}\right)$ adalah 0,218 atau 21,8\%. Jadi variabel broad scope, timeline, agregation, dan integration dapat menjelaskan $21,8 \%$ variasi kinerja manajer dan sisanya $78,2 \%$ dijelaskan oleh variabel lain diluar model.

Tabel 5. Koefisien determinasi

\begin{tabular}{lcccc}
\hline Model & $\mathbf{R}$ & $\begin{array}{c}\mathbf{R} \\
\text { Square }\end{array}$ & $\begin{array}{c}\text { Adjusted R } \\
\text { Square }\end{array}$ & $\begin{array}{c}\text { Std. Error } \\
\text { of the } \\
\text { Estimate }\end{array}$ \\
\hline $1 \quad 0.467^{a}$ & 0.218 & 0.176 & 1.66862 \\
\hline a. & Predictors: & (Constant), & Integration, & Broadscope, \\
Timeliness, Aggregation & & \\
Sumber: output SPSS 24, 2019 & &
\end{tabular}

Uji hipotesis secara parsial (Uji t). Menurut Sugiyono (2016), uji t digunakan untuk mengetahui masing-masing sumbangan variabel bebas secara parsial terhadap variabel terikat, menggunakan uji masing-masing koefisien regresi variabel bebas apakah mempunyai pengaruh yang bermakna atau tidak terhadap variabel terikat.

1. Variabel Broadscope (X1) memiliki nilai signifikansi 0,014 hal ini berarti $\mathrm{Ho}$ ditolak karena nilai signifikan $<0,05$ dan H1 diterima, selain itu memiliki t hitung $2.529>1,697$ sehingga dapat dikatakan bahwa variabel broadscope (X1) berpengaruh secara signifikan terhadap variabel kinerja manajerial.

2. Variabel Timeliness (X2) memiliki nilai signifikansi 0,005 hal ini berarti $\mathrm{Ho}$ ditolak karena nilai signifikan $<0,05$ dan $\mathrm{H} 2$ diterima, selain itu memiliki t hitung $2.889>1,697$ sehingga dapat dikatakan bahwa variabel timeliness (X2) berpengaruh secara signifikan variabel terhadap kinerja manajerial.

3. Variabel Aggregation (X3) memiliki nilai signifikansi 0,044 hal ini berarti Ho ditolak karena nilai signifikan $>0,05$ dan $\mathrm{H} 3$ diterima, selain itu memiliki t hitung 1,752 > 1,697 sehingga dapat dikatakan bahwa variabel Aggregation (X3) berpengaruh secara signifikan terhadap variabel kinerja manajerial.

4. Variabel Integration (X4) memiliki nilai signifikansi 0,086 hal ini berarti $\mathrm{Ho}$ diterima karena nilai signifikan $>0,05$ 
dan $\mathrm{H} 4$ ditolak, selain itu memiliki t hitung $-1,738<1,697$ sehingga dapat dikatakan bahwa variabel Integration (X4) tidak berpengaruh secara signifikan terhadap variabel kinerja manajerial.

Tabel 6. Hasil uji parsial

\begin{tabular}{|c|c|c|c|c|}
\hline \multirow[b]{2}{*}{ Model } & \multicolumn{2}{|c|}{$\begin{array}{l}\text { Unstandardized } \\
\text { Coefficients }\end{array}$} & \multirow{2}{*}{$\begin{array}{c}\begin{array}{c}\text { Standardized } \\
\text { Coefficients }\end{array} \\
\text { Beta }\end{array}$} & \\
\hline & B & Std. Error & & Sig. \\
\hline$\overline{\text { (Constant) }}$ & 34.477 & 3.204 & & 10.7600 .000 \\
\hline Broadscope & 0.475 & 0.188 & 0.264 & 2.5290 .014 \\
\hline Timeliness & 0.620 & 0.214 & 0.298 & 2.8890 .005 \\
\hline Aggregation & 0.339 & 0.193 & 0.183 & 1.7520 .044 \\
\hline Integration & -0.441 & 0.254 & -0.179 & -1.7380 .086 \\
\hline
\end{tabular}

\subsection{Pembahasan}

Pembahasan hipotesis 1 broadscope berpengaruh terhadap kinerja manajerial. Berdasarkan hasil perhitungan regresi berganda untuk broadscope didapatkan nilai t hitung 2,529 > t tabel 1,697 dengan tingkat signifikan sebesar $0,014<0,05$ maka H0 ditolak dan H1 diterima sehingga dapat disimpulkan bahwa variabel boadscope berpengaruh terhadap kinerja manajerial. Karena itu manajer PT Bank SulutGo membutuhkan informasi yang memiliki karakteristik broadscope yaitu informasi yang memiliki cakupan yang luas dan lebih lengkap. Informasi tersebut diantaranya berhubungan dengan kejadian dimasa akan datang sehingga mendukung pengambilan keputusan dan melakukan inovasi.

Pembahasan hipotesis 2 timeliness berpengaruh terhadap kinerja manajerial. Berdasarkan hasil perhitungan regresi berganda untuk timeliness didapatkan nilai t hitung 2,889 $>\mathrm{t}$ tabel 1,697 dengan tingkat signifikan sebesar $0,005<0,05$ maka H0 ditolak dan H1 diterima sehingga dapat disimpulkan bahwa variabel timeliness berpengaruh terhadap kinerja manajerial. PT Bank SulutGo membutuhkan informasi yang tepat waktu (timeliness) yaitu informasi yang terkini sesuai dengan kebutuhan manajer. Informasi yang segera ada saat dibutuhkan dan tidak ada keterlambatan dalam penyampaian informasi (frekuensi pelaporan teratur) menjadi hal yang sangat penting karena informasi tepat waktu akan membantu manajer dalam pengambilan keputusan.
Pembahasan hipotesis 3 aggregation tidak berpengaruh terhadap kinerja manajerial. Berdasarkan hasil perhitungan regresi berganda untuk Aggregation didapatkan nilai t hitung 1,752 > t tabel 1,697 dengan tingkat signifikan sebesar $0,044<0,05$ maka H0 ditolak dan H1 diterima. Sehingga dapat disimpulkan bahwa variabel Aggregation berpengaruh terhadap kinerja manajerial. Selain itu informasi yang disampaikan dalam bentuk lebih ringkas tetapi tetap mencakup mencakup hala-hal penting sehingga tidak mengurangi nilai informasi itu sendiri sangat dibutuhkan oleh PT Bank SulutGo. Adanya penyampaian informasi yang lebih ringkas tanpa mengurangi nilai dari informasi itu sendiri dalam PT Bank SulutGo membuktikan bahwa baiknya kinerja manajer yang juga akan mempengaruhi dalam pengambilan keputusan.

Pembahasan hipotesis 4 integration tidak berpengaruh terhadap kinerja manajerial. Berdasarkan hasil perhitungan regresi berganda untuk Integration didapatkan nilai $\mathrm{t}$ hitung $-1,738<\mathrm{t}$ tabel 1,697 dengan tingkat signifikan sebesar $0,086>0,05$ maka H0 diterima dan H1 ditolak. Sehingga dapat disimpulkan bahwa variabel Integration tidak berpengaruh terhadap kinerja manajerial. Penelitian ini mendukung penelitian sebelumnya Fauziah (2015) menunjukan bahwa karakteristik informasi sistem akuntansi manajemen tidak berpengaruh terhadap kinerja manajerial. Pada PT Bank SuluGo integrasi diantara unit-unit tidak terlalu berpengaruh untuk menigkatkan kinerja manajerial. Hal ini menunjukan semakin rendah karakteristik informasi sistem akutansi manajemen integration maka tidak berpengaruh untuk meningkatkan kinerja manajerial pada PT Bank SulutGo.

\section{Kesimpulan dan saran}

\section{Kesimpulan}

Berdasarkan hasil analisis data dan uji hipotesis pada bab sebelumnya maka dapat disimpulkan bahwa:

1. Variabel broadscope berpengaruh terhadap kinerja manajerial, hal ini dibuktikan dengan hasil uji statistik dimana nilai $\mathrm{t}$ 
hitung 2,529. $\mathrm{t}$ tabel 1,697 dengan tingkat signifikan sebesar $0,014<0,05$ maka H0 ditolak dan H1 diterima. Besarnya pengaruh broadscope terhadap kinerja manajerial sebesar 0,475 atau $4,75 \%$.

2. Variabel timeliness berpengaruh terhadap kinerja manajerial hal ini dibuktikan dengan hasil uji statistik diamana $\mathrm{t}$ hitung 2,889 $>\mathrm{t}$ tabel 1,697 dengan tingkat signifikan sebesar $0,005<0,05$ maka H0 ditolak dan H1 diterima. Besarnya pengaruh timeliness terhadap kinerja manajerial sebesar 0,620 atau $6,20 \%$.

3. Variabel aggregation berpengaruh terhadap kinerja manajerial hal ini dibutkikan dengan hasil uji statistik dimana $\mathrm{t}$ hitung 1,752 > t tabel 1,697 dengan tingkat signifikan sebesar 0,044 $>0,05$ maka H0 ditolak dan H1 diterima.

4. Variabel integration tidak berpengaruh terhadap kinerja manajerial hal ini dibuktikan dengan hasil uji statistik dimana $\mathrm{t}$ hitung $-1,738<\mathrm{t}$ tabel 1,697 dengan tingkat signifikan sebesar 0,086 $>0,05$ maka $\mathrm{H} 0$ diterima dan $\mathrm{H} 1$ ditolak.

\section{Saran}

Setelah melakukan penelitian ini, maka peneliti memberikan saran untuk penelitian selanjutnya, yaitu sebagai berikut.

1. Bagi perusahaan, hasil penelitian ini menunjukan bahwa variabel broadscope, timeliness, dan variable aggregation lebih berpengaruh terhadap kinerja manajerial daripada variabel integration. Hal ini dikarenakan kurangnya pengendalian terhadap penggabungan informasi fungsional dan pengendalian terhadap koordinasi berbagai segmen dalam subsub organisasi.

2. Untuk penelitian selanjutnya diharapkan pengukuran variabel dapat diperluas yang dapat mempengaruhi kinerja manajerial, karena dengan semakin baik kinerja dari manajerial maka akan semakin baik juga bagi perusahaan dalam pengambilan keputusan.

\section{Daftar pustaka}

Abdullah, M. (2014). Manajemen dan Evaluasi Kinerja Karyawan. Yogyakarta: Aswaja Pressindo.

Antameng, D., Lambey, L., \& Gamaliel, H. (2017). Penerapan cost-volume-profit dalam pengambilan keputusan untuk perencanaan laba pada Hotel Fajar Roon Manokwari. Going Concern : Jurnal Riset Akuntansi, 12(01), 91-97. https://doi.org/10.32400/gc.12.01.17141.2017

Bahri, S. (2016). Pengantar Akuntansi. Yogyakarta: Penerbit Andi.

Benawan, E., Saerang, D., \& Pontoh, W. (2018). Pengaruh pengawasan, akuntabilitas dan transparansi keuangan terhadap kinerja pegawai (Studi kasus pada Dinas Perhubungan Kota Tidore Kepulauan). Going Concern : Jurnal Riset Akuntansi, 13(03), $72-79$ https://doi.org/10.32400/gc.13.03.19995.2018

Butarbutar, J., Karamoy, H., \& Tirayoh, V. (2017). Analisis penerapan sistem akuntansi manajemen terhadap pegendalian kualitas produk di PT. Empat Saudara Manado. Going Concern : Jurnal Riset Akuntansi, 12(01), 187-193. https://doi.org/10.32400/gc.12.01.17204.2017

Edison. (2016). Manajemen Sumber Daya Manusia. Bandung: Alfabeta.

Fauziah, N. (2015). Pengaruh Karakteristik Informasi Sistem Akuntansi Manajemen Terhadap Kinerja Manajerial Dengan Ketidakpastian Lingkungan Sebagai Variabel Moderating (Study Empiris Pada Pabrik Gula Pagotan). Skripsi. Fakultas Ekonomi Universitas Muhammadiyah Ponorogo. http://eprints.umpo.ac.id/1304/

Mardi. (2014). Sistem Informasi Akuntansi . cetakan kedua. Bogor : Penerbit Ghalia Indonesia

Nuraidah, R. (2017). Pengaruh Karakteristik Sistem Informasi Akuntansi Manajemen Terhadap Kinerja Manajerial (Studi pada UMKM Batik Kampung Laweyan Surakarta). Skripsi. Fakultas Ekonomi dan Bisnis Islam Institut Agama Islam Negeri Surakarta. http://eprints.iainsurakarta.ac.id/1605/

Prasasti, L. (2017). Pengaruh karakteristik sistem informasi akuntansi terhadap kinerja manajerial (Studi kasus pada PT. Bank Pembangunan Daerah Jambi). Jurnal Manajemen Terapan dan Keuangan, 6(3), 147-225. https://onlinejournal.unja.ac.id/mankeu/article/view/4256

Purba, I., Ilat, V., \& Gamaliel, H. (2018). Pengaruh reinventing policy, sikap rasional, dan keadilan pajak terhadap kepatuhan wajib pajak orang pribadi di KPP Pratama Manado. Going Concern : Jurnal Riset Akuntansi, 13(03), 235-243. https://doi.org/10.32400/gc.13.03.20119.2018

Rivai, Veithzal. (2014). Kepemimpinan dan Perilaku Organisasi. Jakarta: Raja Grafindo Persada.

Sugiyono. (2016). Metode Penelitian Kuantitatif Kualitatif dan Kombinasi (Mixed Methods). Bandung: Alfabeta.

Taniredja, T., \& Mustafidah, H. (2014). Penelitian Kuantitatif. Bandung : Alfabeta.

Wicakcono, W. W. (2014). Pengaruh Karakteristik Infromasi Sistem Akuntansi Manajemen Terhadap Kinerja Manajerial (Survei UMKM Mitra PT. PLN). Skripsi. https:// repository.widyatama.ac.id/xmlui/handl e/123456789/2915. 